\title{
Passive Accomplice or Active Acquiescent to Corruption in Nigeria? Evidence from Newspapers' Sourcing of Information on Corruption from 2000 - 2006
}

\author{
Rodney Ciboh
}

\begin{abstract}
Department of Mass Communication, Benue State University, Makurdi, Nigeria.
Correspondence: Rodney Ciboh, P. O. Box 4982 Makurdi 970101, Nigeria.
\end{abstract}

\author{
Received: April 5, 2014 Accepted: April 21, 2014 Available online: May 30, 2014 \\ doi:10.11114/smc.v2i1.425 \\ URL: http://dx.doi.org/10.11114/smc.v2i1.425
}

\begin{abstract}
This paper uses content analysis to examine newspapers' source use in news of corruption between 2000 and 2006 during Olusegun Obasanjo government's deliberate public policy against the malaise in Nigeria. It examined the sources of news on corruption to discover whose information is presented and to determine whether newspapers showed enterprise and employed investigation to challenge powerful interests and eradicate corruption or they merely acted as agents of such powerful interests behind corruption and reinforced the status quo. The paper found that government/official sources were the most frequently used sources of information on corruption and that newspapers favoured only the official definition of corruption. The paper concludes that by relying heavily on 1 government sources to represent corruption, newspapers more or less actively acquiesced to the status quo on corruption hence journalists lack the courage to investigative and help curb corruption in Nigeria. Until journalists recognise the need for providing pluralistic information about corruption from a diversity and range of sources and multiplicity of perspectives or opinions, they can hardly mobilise possible collective action against corruption in Nigeria and be active participants in strengthening and facilitating democracy.
\end{abstract}

Keywords: corruption, news reporting, news sources, hegemony, newspapers, critical studies

\section{Introduction}

Mass media as main domains for expression of public opinion have always been interpreted in critical theory as agents of a dominant, controlling class of power holders who seek to impose their own definitions of situations and their values, and to marginalise or de-legitimise opposition (McQuail, 2006). The major premise is that the mass media do not define reality on their own but give preferential access to the definitions of those in authority and disseminate a limited and undifferentiated view of the world shaped by the perspectives of ruling interests. That is, media operate primarily to justify and support the status quo at the expense of the ordinary people (Baran and Dans, 1995).

Hall (2006) affirms that the mass media function to maintain the dominance of those already in positions of power and adopts the word 'hegemony' to refer to subtle role of the media to sway of society's haves over its have nots. Hegemony tends to define unacceptable opposition to the status quo as dissent and deviant and by this tendency constrain or condition audiences to accept view of the world offered from the perspectives of ruling interests with little critical response (Murdock and Golding 1977). The result is to maintain and legitimise the prevailing structure of power and to head off change by filtering out alternative voices (McQuail, 2006). As Hall (2006) asserts, "it is not enough that we simply recognise that meaning is created in discourse. We must examine the sources of that discourse especially the originators or speakers of it" (p. 641). The ultimate issue for this paper is therefore not what information is presented but whose information it is.

A good deal of literature supports the conclusion that the Nigerian press rely heavily on official government sources (Ende, 2003; Ciboh, 2005 and Torwel, 2005) in sourcing news and defining situations of conflict and policy. Whose reality of corruption then was presented to the reading public by the newspapers during the period under review? Did Nigerian newspapers investigate corruption or did they operate primarily to maintain the status quo at the expense of society? Rønning (2009) believes that "much of what is presented as investigative journalism in Africa is based on poorly sourced material, often only one source, which has not been properly checked" and that "good and thorough research is frequently lacking." This paper investigates how newspapers constructed the realty of corruption from news 
sources and interpreted the social reality of corruption in response to public policy against it possibly to foster accountability and transparency in government. The paper is interested in how stories were generated, whether newspapers carefully researched stories to help build support for Olusegun Obasanjo's government policy against corruption or gave preferential access to definitions of those in authority and disseminated a limited and undifferentiated view of corruption.

\section{Literature Review}

The media have long been recognised as having a role to play in ensuring that governments are accountable to the governed. Coronel, $(2009$, p.1) says " despite the mass media's propensity for sleaze, sensationalism and superficiality, the notion of the media as watchdog, as guardian of the public interest, and as a conduit between governors and the governed remains deeply ingrained." General perception is that the media are important institutions needed to uncover the abuse of power and economic malpractice (Rønning, 2009). As one of the traditional classic checks and balances in the division of powers, the 'fourth estate' investigates to expose official corruption, corporate scandals, and government failures (Norris, 2000).

Indeed, a responsible and forthright media have become sine qua non for a society that aims at preventing corruption. As Kaufmann (2000) affirms, the media not only raise public awareness about corruption, its causes, consequences, and possible remedies but also investigate and report incidents of corruption, thereby aiding other oversight and prosecution bodies like EFCC and ICPC. Effective media are therefore critical elements of a country's anti-corruption programme. A former World Bank Chief sums it all:

The press is at the absolute core of equitable development because, if you cannot enfranchise poor people, if they do not have a right to expression, if there is no searchlight on corruption and inequitable practices, you cannot build the public consensus needed to bring about change (Wolfensohn 1999, p.64).

Media thus play key roles in investigating allegations of impropriety in public affairs and exposing corruption and corrupt practices. This role becomes even more important when existing political institutions are inadequate and inefficient in ensuring accountability of public servants (Stapenhurst, 2000) especially in a country like Nigeria which is rife with corruption (Smith, 2007) whose image as bastion of bribery, venality, and deceit has remained constant over the years and consistent with perception surveys detailed by Transparency International. Thus both in reality and in perception Nigeria is one of the most corrupt places in the world (Rønning, 2009) and consensus today is that corruption is one of the greatest evils obstructing Nigeria's path towards sustainable development (Achebe, 1983).

Successive governments in Nigeria acknowledge this fact and have tried to stem the pandemic but the cure often turns out to be worse than the disease. But in the words of Odekunle (1986, p. 37), the purported crusade against corruption is often reduced to "occasional intra-elite struggles, squabbles and backstabbing". The government of Olusegun Obasanjo declared war against corruption at its inception in 1999, and established the Independent Corrupt Practices Commission (ICPC) in 2000 and the Economic and Financial Crimes Commission (EFCC) in 2003. Nevertheless, it is no longer a matter of conjecture that President Obasanjo "did little to curb corruption that keeps his oil-rich country poor" (Guest, 2005, p. 262). His administration pursued the anti-corruption policy unfaithfully and "lost the confidence of the people not only because of his failure to deliver on his promises but because he himself was perceived to be highly corrupt" (Smith, 2007 p.116). Consequently, contemporary manifestations of corruption in both public and private sectors in Nigeria since 1999 (Oloja, 2008; The Guardian, 2008 September 8; Alabrah, 2008 October 19; Oloja, Okwe and Jimoh, 2008 September 29; Ali, 2008 October 5 \& 19; Uzendu, 2008 December 10; Ojo, 2011) continue to painfully remind us that corruption is not abating (Adedoja, 2013 April 21; King, 2014 February 06).

Media have constitutional responsibility in Nigeria to make government transparent and accountable but studies on role of the media in Nigeria's political system generally indicate that the press is an instrumental press (Holman, 1972; Bamiduro 1981), that does not provide free flow of information among political structures and between society and policy, but that it operate primarily to strengthen the grip of leaders over their followers, thereby leading to the fragmentation of the country (Oluwajuyitan, 1987; Agbaje, 1993). According to Sobowale (1995), several content analyses on how Nigerian media handle important national and international issues show that primordial factors influence their selection, treatment, and placement of news items. Ugboajah (1986) once examined news appearing in the Nigerian mass media on four key conflict-generating issues of development: corruption, public execution of armed robbers, the 1973 census, and the 1972 public enterprises Decree, in the period 1970-1974. The study found that corruption received the third highest media attention and generated the highest number of anti-government editorials on all issues. Though his study never focused wholly on corruption, it made far reaching conclusions about the press in Nigeria: that both public and private owned newspapers showed a general tendency to take neutral positions on conflict issues and practised survival journalism as a safety valve, that mass media behaviour in Nigeria is consistently pro-power structure especially on volatile issues of development, and that mass media attitude and behaviour appeared 
moulded by the fact of geographical or administrative location more than ownership, and guided by the ethnic constituencies the papers serve.

At inception of Nigeria's fourth republic in 1999, the Nigerian press was applauded for leading the crusade to cleanse the political process of moral and material corruption (Oyovbaire, 2000) particularly the case of forgery and perjury which led to forced resignation of Salihu Buhari, Speaker, House of Representatives. But in their evaluation of ethical and professional standards how objective newspapers were in conveying picture of reality of the cases of forgery and perjury involving Buhari and Tinubu, Idemili and Asogwa (2002) found considerable disparity and lopsidedness in the amount of attention given the two scandals. The press highlighted the Buhari case but downplayed the Tinubu scandal and gave the former twice the weight of attention it gave to the Tinubu case. They concluded that the press employed double standards in the way it reported both cases and adopted a more lukewarm approach to Tinubu's case while the bias against Buhari was evident in the public indignation the press raised against him. According to them,

The press ... saw Tinubu ... as ... a democratic and activist humanist who was being deliberately run aground by his political detractors' intent on perpetrating the status quo ... the Buhari case seems to be consensual show of opprobrium, shock and affront on the supposedly undisguised temerity of the old order intent on carrying on business as usual and totally oblivious or contemptuous of the new democratic spirit in the political scene (Idemili and Asogwa, 2002, p.153).

The International Press Centre Lagos, with support from European Union, also undertook a study on media coverage of four EFCC cases, ICPC activities and other corruption issues in 16 newspapers and magazines, four radio and four television stations in the last quarter of 2005. It found that though there was a high interest by the media in anti-corruption issues, the space devoted to corruption was quite limited when compared with other interest areas (International Press Centre, 2006). It raised critical questions on the credibility of corruption reports, especially the tendency among reporters to make use of anonymous news sources which suggests inability of the newspapers to investigate and generate stories on corruption in line with their constitutional responsibilities.

\subsection{News Sources}

News sources are important in journalism because they attribute meaning to events and shape public perception and understanding (Berkowitz, 2009). Perhaps this explains why Franklin, Lewis, and Williams (2010) said, "an understanding of the relationship between journalists and their sources sits at the heart of journalism studies, (p. 202)." Gans (1979) identified two types of news sources, the knowns and the unknowns. The former are elites and official sources, namely heads of government, ministers and deputy ministers, official spokespersons, leaders of NGOs, experts, celebrities and the like. The latter are ordinary people or non-elites who become relevant sources because of their connections with certain news events as eyewitnesses, victims and families of victims.

The concept of news sources is linked to media codes of ethics, responsible journalism and the obligation to be truthful and report based on full attribution of credible sources (Dholakia and Sternhall, 1977). Journalists' use of sources to fund news with facts about events is the basic tenet of objective journalism (Carlson, 2009). Concerns about believability and credibility of news reports (Kurtz, 2005) have often been basis for criticism against over-reliance on anonymous sources (Ohlmeyer, 2010; Shepard, 2011). Credible sources, it is believed, add authority and believability to news (Atton \& Wickenden, 2005; Detjen, Fico, Li, \& Kim, 2000). Consequently, Strentz, (1989) declares that reporters' credibility is determined not by how news is gathered or quality of news but by thoroughness and accuracy of news through the use of sources.

Hall, Critcher, Jefferson, Clarke and Roberts (1978) place elite sources at top of credibility hierarchy as primary definers of news agenda and interpretative approach used by journalists. His classification of news sources seems compatible with what Manning (2001) calls Hall et al.'s theory of primary definition where primary definers are elites and official sources and secondary definers are those with unequal media access. Described as symbiotic, the relationship between journalists and their sources makes the former so dependable that they rarely work independently and investigate their own stories but generate stories based on information from sources some of whom stand to benefit from the transaction as much as the journalists (O'Neil and O'Connor, 2008). In effect, McNair (1998) says, influential sources acquire power to become definers of journalistic reality.

Numerous studies reveal that elites and government official voices dominate news sources (Lacy and Coulson 2001; Althaus, Edy, Entman, and Phalen 1996; Entman and Page 1994; Ende, 2003; Ciboh, 2005 and Torwel, 2005). By granting elites and official sources what the Glasgow University Media Group calls 'hierarchy of access' (Atton, 2002a, pp. 10-11), Schlesinger and Tumber (1999) say "journalistic practice generally promotes the views and interests of authoritative sources" (p.260) which rarely stray far from the status quo. By depending heavily on official government sources, Matthews (2013) argues, journalists "rely on a small number of sources" and "risk relaying misleading information as news while, at the same time, permitting these sources to shape the boundaries of interpretation around an issue or event" (p.243). 
But the extent to which the less powerful and politically marginal can obtain media access, Cottle (2003) argues, is one of the most significant debates concerning journalism's democratic function as an independent monitor of the privileged and powerful. Expectations are that media must facilitate democracy by providing pluralistic information from a diversity and range of sources and various opinions from a multiplicity of perspectives in news for informed choices to be made and debates to take place (Manning, 2001). A diversity and range of sources and multiplicity of perspectives according to (Matthews, 2013), is fundamental to questions of balance, accuracy and impartiality. Balance often refers to less narrow representation of viewpoints within specific stories news by using balanced facts provided by multilevel sources and not just by a single source. Thus, Tiffen et al (2013) say, the questions whether there are diversity of sources in the news or there is a balance of sources in the news, or some source types dominate are very pertinent.

\subsection{Theoretical Framework}

This study is embedded in cultural studies defined by Bennett (1998:60) as "concerned with the analysis of cultural forms and activities in the context of the relations of power which condition their production, circulation, deployment and, of course, effects." Critical theory has several variants, especially the cultural and the political economy forms. From the political economy point of view, the media institution is considered a part of the economic system with close links to the political system. Critical political economy theory therefore identifies a socially critical approach that focuses primarily on the relation between the economic structure, dynamics of media industries and the ideological content of media (McQuail, 2006). It directs research attention to the empirical analysis of the structure of ownership and control of media and to the way market forces operate.

Critical scholars of the political economy variant argue that media are ideological agencies which play a central role in maintaining class domination. They search for answers to the question of power of the media in the analysis of their structures of ownership and control and by analyses of the professional ideologies and practices found in these organisations (Gurevitch, Benneth, Curran, and Woolacott, 1990). The political economy approach thus examines the relationship between media institutions and the political and economic institutions of society. According to Garnham (1979), the predominant character of what media produce can be largely accounted for by the exchange value of different kinds of content under conditions of pressure to expand markets, and by the underlying economic interests of owners and decision makers. Effects of these economic forces, Murdock and Golding (1977) declare, are not random but work consistently to exclude

...those voices lacking economic power and resources...the underlying logic of cost operates systematically, consolidating the position of groups already established in the main mass media markets and excluding those groups who lack the capital base required for successful entry. Thus the voices which survive will largely belong to those least likely to criticise the prevailing distribution of wealth and power. Conversely, those most likely to challenge these arrangements are unable to publicise their dissent or opposition because they cannot command resources needed for effective communication to a broad audience (Murdock and Golding 1977, p.37).

Critical theory is especially concerned with addressing the forms of systematic exclusion associated with the social, economic and political status quo, insofar as the established system often replicates entrenched power relations which have detrimental effects on systematically excluded groups (Hayden and el-Ojeili, 2006). Major premise here is that mass media do not define reality on their own but give preferential access to definitions of those in authority and disseminate a limited, undifferentiated view of the world shaped by perspectives of ruling interests hence they operate primarily to justify and support the status quo at the expense of ordinary people (Baran and Dans, 1995).

Critical theory presupposes that people are oppressed by those who control the culture and that economic ownership and advertising, government policies and labour processes which go into the production, distribution and consumption of communication all influence media behaviour and content (McChesney, 2000). Many scholars concede that because the media conform to a general capitalist type of industry, they are likely to be in the monopolistic ownership of a capital owning class and to be nationally or internationally organised to serve the interest of political and economic power holders (Murdock and Golding, 1977; Gurevitch, Benneth, Curran, and Woolacott, 1990). Hence, to McQuail (2006), media work ideologically by disseminating the ideas and world views of the ruling class, denying access to alternative ideas which might lead to change or to a growing consciousness on the part of the working class of its interests, and by hindering the mobilisation of such consciousness into active and organised political opposition.

Hall (2006) consents that private control of public communication tends to maintain the status quo by constraining free expression and the average citizen is blissfully unaware of that fact. Media hegemony tends to prop up the status quo by privileging the already accepted interpretation of reality and the role of the media turns out to be production of consent rather than a reflection of consensus (Greenberg, 2000). The concept of hegemony brings together ideas how the culture of media (news, entertainment, fiction) helps to maintain the class divided and class dominated society. From analysis of Stoddart (2007), hegemony presupposes an interrelated set of ruling ideas permeating a society but in such a way as 
to make the established order of power and values appear natural, taken for granted and commonsensical. Thus, hegemony tends to constrain or condition audiences to accept the world view of the world offered from the perspectives of ruling interests with little critical response (Stoddart, 2007). The result is to maintain and legitimate the prevailing structure of power and to head off change by filtering out alternative voices (Hall, 2006).

The task of critical theory is to raise our consciousness of the media's role in preserving the status quo. Shoemaker and Reese (1996), Herog and McLeod (1995), Herman and Chomsky (1988), and others, have also affirmed that media reflect the interests of the existing power structure, support the status quo through several categories of influences, including the biases of individual journalists, professional converting practices, and ideologies; organisational imperatives; economic ties; socio-cultural world views and hegemonic ideology. This tendency is seen by Altschull, (1984) as further evidence of hegemony in society where ruling class definitions of events rule but without direct action taken by the ruling class themselves

In the location of media power in the economic processes and structures of media production, Murdock and Golding (1977) contend that the role of the media is that of legitimating, through the production of false consciousness, the interests of a class which owns and controls the media. In critical analysis of media structure and economics, Gurevitch, Benneth, Curran, and Woolacott, (1990) regard media institutions as at best relatively and marginally autonomous. Thus, media are regarded as being blocked into the power structure, and as consequently acting largely in tandem with dominant institutions in society such that they reproduce the viewpoints of dominant institutions not as alternative perspectives, but at the central and obvious or natural perspective.

\section{Method}

This study uses content analysis to examine newspapers' source use in news of corruption. News coverage of six major Nigerian newspapers was considered for a period of six years from June 2000, when President Olusegun Obasanjo formally signed the Corrupt Practices and Other Related Offences Act at Abuja into law, to December 2006. But actual sampling of months began six months later, January 2001. This was to allow the law enough time to take effect and the phenomenon of corruption ample period to manifest in the news.

Hard copies of the six newspapers were obtained through multi-stage sampling. First, six newspapers were selected through a random raffle. Second, six monthly samples of each newspaper were drawn at random during the period, in fixed intervals of two months and in a rotating procedure of odd months from odd years and even months from even years to ensure equitable distribution. Third, sampling of units or issues was systematically drawn from composite weeks of five working days each, amounting to 180 sampling units or issues for the six newspapers. In the final stage, a purposive sample of 283 news stories on corruption was taken.

From these traditional fact-based straight news accounts, sources were coded by the researcher and a second independent coder for analysis and for determination of inter-coder reliability using Scott's $p i$ (Wimmer and Dominic, 2000 , p. 152). The study posted a reliability coefficient of .92 (Scott's pi), which affirmed a high degree of agreement between the two coders. Reliability of the study was validated on face value. Source is defined as the name of a person, group, institution, or organisation associated with direct or indirect quotes in a story.

\section{Results}

Results show news on corruption tends to be weighted toward government/official sources, giving disproportionate attention to those who have political and/or economic power most frequently than each of the other sources. Nigerian elites such as the president/presidency, state governors/governments, legislators, ministers, commissioners, politicians, including heads of government departments, accounted for over one third (37.25\%) of all sources (Table 1). The average mean use of government or public officials stood at about 19 sources per newspaper. That is, public officials appeared three times more frequent as news sources compared to the all other sources used by newspapers across the board.

Table I. Percentage of Sources used in News Stories among Newspapers

\begin{tabular}{|c|c|c|c|c|c|c|c|c|}
\hline \multicolumn{9}{|c|}{ NEWSPAPERS } \\
\hline & D/Champion & D/Trust & T/Guardian & The Punch & This Day & Vanguard & Total & $\%$ \\
\hline \multicolumn{9}{|l|}{ SOURCES } \\
\hline Anonymous & 01 & 00 & 02 & 03 & 02 & 03 & 11 & 3.68 \\
\hline Experts & 03 & 01 & 04 & 03 & 02 & 00 & 13 & 4.35 \\
\hline Individuals & 00 & 00 & 02 & 02 & 00 & 01 & 05 & 1.67 \\
\hline Interest Groups & 03 & 01 & 02 & 04 & 06 & 02 & 18 & 6.02 \\
\hline Media & 01 & 02 & 01 & 04 & 02 & 01 & 11 & 3.68 \\
\hline Organisations & 00 & 00 & 01 & 00 & 02 & 01 & 04 & 1.34 \\
\hline Police & 01 & 01 & 00 & 06 & 02 & 02 & 12 & 4.03 \\
\hline Public Officials & 18 & 14 & 17 & 30 & 21 & 11 & 111 & 37.25 \\
\hline Spokespersons & 08 & 05 & 03 & 12 & 06 & 03 & 37 & 12.37 \\
\hline Staff-reporters & 05 & 09 & 08 & 23 & 15 & 17 & 77 & 25.75 \\
\hline Total & & & & & & & 299 & 100 \\
\hline
\end{tabular}


Results also show that slightly above a quarter $(25.75 \%)$ of all sources used in news of corruption during the period was sourced from the newspapers' staff reporters. Staff reports were mostly sourced from court proceedings, legislative processes, workshops and seminars. Most of stories which appeared to suggest enterprise, both on the part of the reporter and the newspaper organisation, to actively go out an investigate corruption, especially high profile cases involving public officials, were characterised with anonymous sources such as 'sources close to', 'according to our source,' 'a top shot,' Vanguard was informed,' 'according to presidency sources,' 'our correspondent gathered,' 'it was gathered,' 'sources close to management,' 'findings by our correspondent,' 'according to Thisday checks.' One-third of all sources used were anonymous sources.

Newspapers also used a substantial amount of spokespersons of the various government departments, institutions and the police in relatively high percentage $(12.37 \%)$ in their stories. Interest groups such as labour or trade unions and professional groups accounted for 6.02 per cent of all sources. Stories generated by interest groups were mostly calls and petitions to investigate corruption. Experts, mostly lawyers and financial experts appeared in relatively small $(4.35 \%)$ percentages. A roughly equal proportion and percentage $(4.01 \%)$ of stories were sourced from police sources as well as from experts (4.35\%), other than police spokespersons.

\section{Discussion}

The data analyzed for this study illuminate a number of ways in which the use of sources in newspaper coverage of corruption worked to marginalize ordinary people. Analysis of results shows that newspapers depended heavily on government officials and allowed official sources associated with powerful positions or institutions, such as the president/presidency, state governors/governments, legislators, ministers, commissioners, politicians, including heads of government departments to offer "primary definition" of corruption. These results confirm earlier studies (Torwel, 2005; Ciboh, 2005; Ende, 2003 that Nigerian newspapers rely heavily on government official sources of information in issues of policy and conflict. Non-elite sources made up a small minority of news sources. Interest groups such as labour or trade unions and professional groups accounted for 6.02 per cent of all sources. Stories generated by interest groups were mostly calls and petitions to investigate corruption. Experts, mostly lawyers and financial experts appeared in relatively small $(4.35 \%)$ percentages. Results also validate general conviction that journalists canvass official sources routinely and rely heavily on official sources (Fishman, 1980; Paletz \& Entman 1981; Sigal, 1973; Shoemaker and Reese, 1996; Soley, 1992).

Such structured hierarchy of access by elite sources to news discourse only tends to framing of news content that favours the powerful (Cross, 2010). Especially in stories of corruption involving political leaders, newspapers relied on a single source which neither provides checks on what is said nor brings variety and balance to the views presented. In a news story titled "N150m fraud uncovered" in a state civil service for instance, Daily Champion (2001, November 27) relied only on what Governor Segun Osoba said to report the fraud without any collaboration of the official government version. In another story in which House of Representative Committee probing public Treasury queried FIRS over alleged disappearance of N28 billion oil fund, Daily Champion (2002, April 17) again only quoted a committee chairman without any attempt to investigate and seek balance to the official position. Such stories, based on single sources, only allow such sources' views of events to be carried unchallenged, and reflect a passive orientation whereby news acts as a conveyor belt rather than a testing ground for what powerful figures are saying (Tiffin et al, 2013).

Newspapers also used official spokespersons of the various government departments, institutions and the police. Combined with elite sources, official government sources represented for more than half (54.03\%) of all sources used by newspapers to interpret the reality of corruption. By depending heavily on official government sources, journalists relied on a small number of sources and risked relaying misleading information as news while, at the same time, permitting these sources to shape the boundaries of interpretation around corruption (Matthews, 2013). Apparently, need for plurality of sources in defining a serious social problem and policy issue like corruption and allowing citizens access to multiple points of view was largely ignored by newspapers. O'Neil \& O'Connor (2008) fear reliance on a small number of sources may ultimately reduce the quality of reporting and even diminish journalism's capacity to act in the public interest. Given that these elite sources are practitioners of grand corruption in Nigeria, it appears, and must agree with McQuail (2006) that newspapers worked ideologically to deny access to alternative ideas which might have led to change or to a growing consciousness among Nigerians and to hinder mobilisation of such consciousness into active and organised opposition against corruption.

Evidently, newspapers compromised journalism's democratic function as an independent monitor of the privileged and powerful (Cottle, 2003) and failed to facilitate democracy by providing pluralistic information from a diversity and range of sources and a multiplicity of perspectives on corruption for informed choices to be made and debates to take place (Manning, 2001). Consequently, it becomes doubtful if newspapers did not head off change by filtering out alternative voices, ideas and views which might have led to success of the policy or at least to an increased potential for 
mobilisation into active and organised fight against corruption. But inclusiveness in democratic processes, Young (2000) argues, "suggests that there must be a single public sphere, a process of interaction and exchange through which diverse sub-publics argue, influence one another, and influence policies and actions of state and economic institutions" (p. 172). Invariably, mass media are crucial facilitators of public discourse in general but they are particularly salient for publics whose concerns and/or viewpoints fall outside the mainstream

There was hardly any evidence of investigative reporting by the newspapers. Most newspaper stories especially high profile cases of fraud, embezzlement and looting of public funds involving public officials that passed for reporter enterprise or as investigative journalism were poorly sourced (Rønning, 2009). These were characterised with anonymous sources such as 'sources close to', 'according to our source,' 'a top shot,' Vanguard was informed,' 'according to presidency sources,' 'our correspondent gathered,' 'it was gathered,' 'sources close to management,' 'findings by our correspondent,' 'according to Thiday checks. Anonymous sourcing can be justified on basis that risks associated with coverage of organised crime and corruption are high and journalists often are subjected to threats, intimidations, physical force, and outright loss of life (UNESCO, 2012; World Association of Newspapers, December 2011) especially in a country like Nigeria with culture of impunity and lawlessness (Adedoja, 2013 April 21). But by attributing their comments to unnamed officials, media outlets often allow public figures to escape accountability and scrutiny (Kurtz, 2010) and more frequently, "they sink to being government's managerial tool, putting journalists on slippery moral ground" (Son 2002, p. 170). Consequently, out of fear of punitive reprisals, or simply out of malicious acquiesce or out of the corrupt generating influence (Odekunle, 1986), journalists never summoned investigative journalism to fight corruption.

Results also show that about a quarter of all sources used during the period were newspapers' staff reporters. Staff reporters sourced news of corruption mostly from organised events such as court proceedings, legislative processes, workshops and seminars, press briefings, public ceremonies, and prepared handouts at such events or signed statements from public officials or spokespersons, anti-corruption agencies, and government departments. Obviously, newspapers published most news of corruption from staged events and prepared statements suggesting that such pre-packaged material reduced the diversity of perspectives represented in news (O'Neil and O'Connor, 2008) and "journalism risks becoming open to manipulation and misinformation" (Mathews, 2013, p.246).

\section{Conclusion}

From evidence, it is hardly conjectural that newspapers justified and supported the status quo on corruption at the expense of the ordinary people, and merely confirmed their agency role as instruments and agents by which the power elite exercise social control (Hall, 2006). Clearly, Nigerian newspapers still serve the corrupt leadership as agents and mouthpieces of oppression and operate primarily to strengthen the grip of leaders on followers (Agbaje, 1993; 2001) and are even held captive by the ruling elites (Egbon, 2002).

By relying entirely on privileged government sources and allowing them to frame the news directly, newspaper reports on the most serious cases of corruption were reduced, ostensibly, to one-sided accounts at the expense of details, balance, and completeness. Undoubtedly, newspapers not only failed to meet McQuail's (2006) definition of impartiality as "balance in the choice and use of sources, so as to reflect different points of view, and also neutrality in the presentation of news ..." (p.321) but also trivialised serious cases of corruption, reducing them to feigned intra-elite struggles, squabbles, and backstabbing (Odekunle, 1986). Until newspapers insist on variety of sources, recognise the need for plurality of news sources, can they help in their tangible role of providing citizens with accurate and useful information to mobilise possible collective action against corruption in Nigeria.

\section{References}

Achebe, C. (1983). The trouble with Nigeria, Enugu: Fourth Dimension Publishers.

Adedoja, T. (2013, April 21). US Report: There's Massive Corruption in Nigeria. http://www.thisdaylive.com/articles/us-report-there-s-massiveorruption-in-nigeria/145531/.

Agbaje, A. (2001). Comparative assessment of media performance in the second and fourth Nigerian republics'. A Paper Presented at the Media in Democracy Workshop Organized by the Institute of Media and Society IMS, in Collaboration with Conciliation Resources United Kingdom Held at the University of Ibadan Conference Centre, Ibadan Oyo State $3^{\text {rd }}-7^{\text {th }}$ September.

Agbaje, A. (1993). The Nigerian Press, Hegemony and Social Construction of Legitimacy, 1960-1983. Lewiston: The Edward Million Press.

Alabrah, D. (2008, October 19). How DGs, Board members ripped of NIPSS. Sunday Sun, FP and PP.4\&8

Ali, Y. (2008, October 5). N557m arms scandal: ICPC may declare Ehindero wanted. The Nation, FP \&P.8 
Althaus, S. L., Edy, J. A., Entman, R. M., \& Phalen, P. (1996). Revising the indexing hypothesis: Officials, media, and the Libya Crisis. Political Communication, 13(4), 407- 421. http://dx.doi.org/10.1080/10584609.1996.9963128

Altschull, J.H. (1984). Agents of Power: The role of the news media in human affairs. New York: Longman.

Atton, C. (2002a). Alternative Media, London: Sage.

Atton, C., \& Wickenden, E. (2005). Sourcing Routines and Representation in Alternative Journalism: A case study approach. Journalism Studies, 6(3), 347-359. http://dx.doi.org/10.1080/14616700500132008

Bamiduro, S. O. (1981). The politics of the Nigerian Press: An analysis of press viewpoints on three fundamental issues of post independence politics. PhD Dissertation. New York: The John Hopkins University.

Bennett, T. (1998). Culture: A reformer's science. London: Sage.

Baran, J. S. \& Dans K. D. (1995). Mass Communication Theory: Foundations, Ferment and Future; Australia: Thompson/Wadsworth.

Berkowitz, D. A. (2009). Reporters and Their Sources. In The Handbook of Journalism, edited by Karin Wahl-Jorgensen and Thomas Hanitzsch, 10215. New York: Routledge. http://www.rasaneh.org/Images/News/AtachFile/30-9-1390/FILE634600594129473750.pdf

Carlson, M. (2009). Dueling, Dancing, or Dominating? Journalists and Their Sources. Sociology Compass, 3(4), 526-542. http://dx.doi.org/10.1111/j.1751-9020.2009.00219.x

Ciboh, R. (2005). The Media and Conflicts in Nigeria: Attribution Bias in Press coverage of the Tiv-Jukun Crisis 2001. In A. M Yakubu, R. T. Adegboye, C. N. Uba and B. Dogo (Eds) Crisis and Conflict Management in Nigeria since 1980 (pp. 199-220). Kaduna: Nigerian Defence Academy.

Coronel, S. (2009). Corruption and the watchdog role of the news media. In Pippa Norris (ed.) Public Sentinel: News Media \& Governance Reform. The World Bank: Washington DC.

http://www.hks.harvard.edu/fs/pnorris/Acrobat/WorldBankReport/Chapter\%205\%20Coronel.pdf

Cottle, S. (2003). News, Public Relations and Power, London: Sage.

Cross, K. A. (2010). Experts in the news: The differential use of sources in election television news. Canadian Journal of Communication, 35, 413-429

Detjen, J., Fico, F., Li, X., \& Kim, Y. (2000). Changing Work Environment of Environmental Reporters. Newspaper Research Journal, 2l(1), 2.

Dholakia, R. R., \& Sternhall, B. (1977). Highly Credible Sources: Persuasive Facilitators or Persuasive Liabilities? The Journal of Consumer Research, 3(4), 223-232.

Egbon, M. (2002). The mass media in Nigeria's democratic dispensation. In Jega, A. M., Wakili, H. and Ahmad Mustafa (eds) Democracy and democratisation in Nigeria. Kano: Centre for Democratic Research and Training

Ende, T. S. (2003). Pluralism in news and editorials in Nigerian newspapers. Masters thesis. Benue State University, Makurdi.

Entman, R. M., \& Page, B. I. (1994). The news before the storm: The Iraq War debate and the limits to media independence. In L. W. Bennett and D. L. Paletz. (Eds).Taken by storm: The media, public opinion, and U.S. foreign policy in the Gulf War. (pp. 202-212). Chicago, Illinois: University of Chicago Press.

Fishman, M. (1980). Manufacturing News. Austin Texas: University of Texas Press.

Franklin, B., Lewis, J., \& Williams, A. (2010). Journalism, News Sources and Public Relations. In S. Allan (Ed.), The Routledge Companion to News and Journalism (pp. 202-212). New York: Routledge.

Gans, H. J. (1979). Deciding What's News: A Study of CBS Evening News, NBC Nightly News, Newsweek, and TIME. New York: Pantheon Books.

Garnham, N. (1979). Contribution to a political economy of mass communication media. Culture and Society, 1, 2.

Greenberg, J. (2000). Politics, Protest and the Press: New Right Hegemony, Crisis Discourse and the 1997 Ontario Teachers' Strike. Open Access Dissertations and Theses. Paper 6808.

http://digitalcommons.mcmaster.ca/opendissertations

Guest, R. (2005). The shackled continent. London: Pan Books

Gurevitch, M., Bennett, T., Gurran. J. \& Wollacott. J. (1990). (Eds.) Culture, society and the media. London: Routledge.

Hall, S., Critcher, C., Jefferson, T., Clarke, J. N., \& Roberts, B. (1978). Policing the Crisis: Mugging, the State, and 
Law and Order. London: Macmillan.

Hall, A. (2006). Reading realism: audiences' evaluations of the reality of media texts. Journal of communication, 53(4), 624-641. http://dx.doi.org /10.1111/j.1460-2466.2003.tb02914.x

Hayden, P., \& el-Ojeili, C. (2006). Critical Theories of Globalization. New York: Palgrave Macmillan.

Herman, E. S. \& Chomsky, N. (1988). Manufacturing Consent: The Political Economy of Mass Media. New York: Panthcon Books.

Herlog, J. K. \& McLeod, D. M. (1995) Anarchies wreak havoc in downtown Mineapolis: A multi-level study of media coverage of radical protest. Journalism Monographs, 151.

Holman, H. L. (1972). The press and politics in Nigeria. PhD Dissertation, Columbia University, New York.

Idemili, S. O., \& Asogwa, F. N. (2001). Objectivity on Trial: The Buhari/Tinubu Scandals and the Nigerian Press. Nsukka Journal of the Humanities, No. 12.

International Press Center. (2006, January 6). 'The Anti-Corruption Summary'. The Guardian P.11

Kaufmann, D. (2000). Foreword. In Rick Stapenhurst. The Media's role in curbing corruption. World Bank Institute.

King, A. (2014, February 06). EFCC's fund paucity shows Jonathan's unwillingness to fight corruption'. http://dailyindependentnig.com/2013/12/efccs-fund-paucity-shows-jonathansunwillingness-fight-corruption/ on February 3, 2014.

Kurtz, H. (2005, May 17). Newsweek retracts Guantanamo story. The Washington Post, p. A3.

Kurtz, H. (2010, June 15). Don't use my name: The anonymity game. Washington Post. http://www.washingtonpost.com/wpdyn/content/article/2010/06/15/ AR2010061501315.html.

Lacy, S., \& Coulson, D. C. (2001). Comparative case study: Newspaper source use on the environmental beat. Communication Abstracts, 24(1), 13-25.

Matthews, J. (2013). Journalists and their sources: The twin challenges of diversity and verification. In K. Fowler-Watt and S. Allan Eds. Journalism: New Challenges. (pp. 242-258). Bournemouth: Centre for Journalism \& Communication Research Bournemouth University.

Manning. P. (2001). News and News Sources: A Critical Introduction, London: Sage.

McChesney, R. (2000). Rich media, poor democracy. New York: New Press

McNair, B. (1998). The Sociology of Journalism. London; New York: Arnold and Oxford University Press.

McQuail, D. (2006). Mass Communication Theory: An Introduction. London: Sage Publications.

Murdock, G., \& Golding, P. (1977). Capitalism, communication and class relations. In D. Curran (ed.) Mass communication and society. London: Edward Arnold.

Norris, P. (2000). A Virtuous Circle: Political Communications in Post-Industrial Societies. NY: Cambridge University Press.

Odekunle, F. (1986). Nigeria: Corruption in Development, (Ed), Ibadan: Ibadan University Press.

O’Neill, D., \& O,Connor, C. (2008). The passive journalist: How sources dominate local news. Journalism Practice, 2(3), 487-500.

Ohlmeyer, D. (2010). Root of all evil? Even with policies in place, ESPN must use caution when relying on anonymous sources. $\quad$ ESPN.com. $\quad$ Retrieved $\quad$ March 28 28, 2014 from http://sports.espn.go.com/espn/columns/story?columnistDohlmeyer_don \& idD52204 92

Ojo, E. O. (2011). Nigeria's Nascent Democracy and 'War' Against Corruption: A Rear View Mirror. Africa Research Review, 5(2), Serial No. 19, Pp. 56-71.

Oloja. (2008, July 14). Accountant-General lists points of corruption in government'. The Guardian, FP \& P.2

Oloja, M., Okwe, M., \& Jimoh, A.M. (2008, September 29). Senate Panel Uncovers N786 fraud in banks. The Guardian, FP and P.2

Oluwajuyitan, J. (1987). Mass media and national integration in Nigeria: An Examination of the Nigerian press. $\mathrm{PhD}$ Dissertation, University of Lagos.

Oyovbaire, S. (2000). Pluralism and the media. In Report of workshop on media and democracy (pp. 77-96). Abuja: Nigerian Press Council. 
Paletz, D. L., \& Entman, R. M. (1981). Media Power and Politics. New York: Free Press.

Rønning, H. (2009). The politics of corruption and the media in Africa. Journal of African Media Studies, 1(1), 155-171. http://dx.doi.org/ 10.1386/jams.1.1.155/1

Schlesinger, P., \& Tumber, H. (1999). Reporting Crime: The Media Politics of Criminal Justice. In H. Tumber (Ed), News: A Reader (pp. 257-266). Oxford: Oxford University Press.

Shepard, A. (2011). NPR's Giffords mistake: Re-learning the lesson of checking sources. http://www.npr.org/blogs/ombudsman/2011/01/11/132812196/nprsgiffords-mistake-re-learning-the-lesson-of-chec king-sources.

Shoemaker, P. J., \& Reese, S. D. (1996). Mediating the Message. $\left(2^{\text {nd }}\right.$ Ed.) White Plains NY: Longman.

Sigal, L. V. (1973). Reporters and Officials: The Organization and Politics of Newsmaking. Lexington, Mass.: D. C. Heath.

Sobowale, I. (1995). Nigerian Press Coverage of National Issues. In Akinfeleye, R. Omole, G. and Omang, O. (eds) Nigerian Mass Media and National Crises (pp. 57-86). Lagos: Nigeria Press Council.

Soley, L.C. (1992). The news shapers: The sources who explain the news New York: Praeger

Son, T. (2002). Leaks: How do codes of ethics address them? Journal of Mass Media Ethics, 17(2), 155-173.

Smith, D. J. (2007). A culture of corruption: Everyday deception and popular discontent in Nigeria. United Kingdom: Princeton University Press

Stapenhurst, R. (2000). The Media's Role in Curbing Corruption. Washington DC: World Bank Institute Retrieved February 17, 2014 from http://www.worldbank.org/wbi/governance/pdf/media.pdf

Stoddart, M. C. J. (2007). Ideology, Hegemony, Discourse: A Critical Review of Theories of Knowledge and Power. Social Thought \& Research, 28, 191-226.

Strentz, H. (1989). News Reporters and News Sources: Accomplices in Shaping and Misshaping the News. Iowa: Iowa State University Press.

Tiffen, R., Jones, P. K., Rowe, D., Aalberg, T., Coen, S., Curran, J., ... Soroka, S. (2013). Sources in the news: A comparative study. Journalism Studies. http://dx.doi.org/10.1080/1461670X.2013.831239

Torwel, V. (2005). Framing Political Conflict in a Multi-ethnic Democracy: A Critical Analysis of the News of the 2001 Nigeria Tiv-Jukun Conflict. A Paper Presented at the Ph.D Convention School of Journalism and Mass Communication, the University of Iowa, Iowa City March 25.

Ugboajah, O. F. (1986). Mass Communication, Culture and Society in West Africa. New York London Paris: Hans Zells Publishers.

UNESCO. (2012). Safety of journalists and the danger of impunity PARIS: UNESCO. http://www.unesco.org/new/fileadmin/MULTIMEDIA/HQ/CI/CI/pdf/IPDC/ipdc28_dg_safety_report_final_rev.pdf

Uzendu, M. (2008 December 10). 'N2.3bn car scam: money traced to Reps account'. Daily Champion, P.6.

Wimmer, R. D., \& Dominick, J. R. (2000). Mass Media Research: An Introduction. Belmont, E. A: Wadsworth Publishing Company.

World Association of Newspapers. (December 2011). World's Most Dangerous Region for Journalists: the Arab World http://www.wan-ifra.org/articles/2012/01/05/world-s-most-dangerous-region-for-journalists-the-arab-world

Wolfensohn, J. (1999). Being a Speech to the World Press Freedom Committee. Washington DC, November 8. http://www.worldbank.org/wbi/governance/pdf/media.pdf

Young, I. M. (2000). Inclusion and Democracy. Oxford Series in Political Theory. Oxford: Oxford University Press.

\section{(cc) BY}

This work is licensed under a Creative Commons Attribution 3.0 License. 